\title{
Population Growth and Its Impact on Urban Expansion: A Case Study of Bahawalpur, Pakistan
}

\author{
Asad Ali Khan*, Sana Arshad, Muhammad Mohsin \\ Department of Geography, The Islamia University of Bahawalpur, Pakistan \\ *Corresponding Author: asadkhaniub@yahoo.com
}

Copyright (c) 2014Horizon Research Publishing All rights reserved.

\begin{abstract}
Land cover analysis and land use transformations, which are mainly associated with population growth, are considered as essential elements for studying the relationship between population growth, land use conversions and environmental consequences. Most cities of the world are becoming urbanized with every passing day and human induced land cover changes are modifying the pattern of land use in urban areas. Currently, Pakistan is standing at an influential place with regard to the size of its population, occupying sixth position among the world countries. Almost all its administrative entities have experienced unprecedented population growth throughout its entire life. Its urban areas are expanding more rapidly than their rural counterparts due to both by natural increase and by rural-urban migration. Study area for the current research, Bahawalpur is one of the fastest growing cities of Pakistan ranking twelfth among the cities of Punjab Province. This study aims at to examine the historical population growth of the city since last fifty years correlated with changing land use pattern and urban area expansion. Study is based on secondary data analysis using urban expansion indices for measuring the rate of urban change with increasing population growth. Application of regression model also verifies the increasing rate of urban area with population size and indicates an alarming situation for urban and city planners. Trend of urban growth in Bahawalpur shows that city is moving promptly towards highly urbanized cities of Pakistan. Its unprecedented and unplanned expansion may cause serious urban problems. Thus, it needs a serious look and attention of city planners. This study can also be helpful in providing some base line information.
\end{abstract}

Keywords Population Growth, Urban Expansion Ratio, Land Use Pattern, Urban Change

\section{Introduction}

Population growth is increase in number of (per hundred) people inhabiting in a given area over a given period of time whereas urbanization is a process of population concentration in a specific area. Urbanization usually proceeds in two ways; the multiplication of point of concentration and the increase in the size of individual concentration (Tisdale, 1941). Pham and Yamaguchi (2011)have defined the urbanization as "Changes in the territorial extent of an area due to developed transformation of land covers/ land uses from non-developed". Urbanization can be discussed in two ways; the level of urbanization (existing situation of a region at any particular moment), and tempo of urbanization which refers to "trend of urban development” (UN, 1974).

Increase in urban share of total population called "urbanization" is determined by three factors namely; natural growth, rural-urban migration, and reclassification of areas from rural to urban (Buhaug \& Urdal, 2013).This process takes place due to the intensification of human activities including marketization and industrialization. It is expected that by the mid $20^{\text {th }}$ century every $3^{\text {rd }}$ person will be living in urban areas with faster demographic expansion and rural urban migration. More than three billion people will be residing in cities especially in Africa and Asia (Buhaug \& Urdal, 2013; Pham, et al., 2011; UNHABITAT, 2010).

Numerous studies support the evidence of rapid urbanization as a result of human induced land use/ land cover changes (Aljoufie, Zuidgeest, Brussel, \& van Maarseveen, 2013; Briassoulis, 2000; Halder, 2013; H. Zhang, Qi, Ye, Cai, \& Ma, 2013; Z. Zhang, Su, Xiao, Jiang, \& Wu, 2013). It is a common observation that with growing population, urban areas are expanding. The rate of expansion, however, depends upon several other associated factors. It is understandable and several studies also argue that human population growth and resource consumption leads to the expansion of urban land area and bring changes in its land use and land cover (Cheng \& Masser, 2003; Haregeweyn, Fikadub, Tsunekawa, \& Tsubo, 2012; Tian et al., 2005). Land use is the varying activities performed by human beings to divide the landscape into different patterns with concerned changes (Carole L.Jolly \& Barbara Boyle Torrey, 1993) and varies with human activities and the purpose for which land is being used. It can be used for food production, provision for shelter, recreation, processing of materials, and so on (Halder, 2013). Historical evidences demonstrate that 
cities always have capacitated rapidly due to mass migration of people, high growth rate, and provision of facilities and services. They play significant role in boosting economic conditions and strengthening the countries finance.

However, cities of the developing countries are facing many challenges because of accelerated urbanization. In cities, infrastructure and services, over crowded transportation systems, insufficient water supply, deteriorating sanitation, and environmental pollution are the major consequences of urban growth and factors responsible for environmental degradation (Buhaug \& Urdal, 2013; Herold, Goldstein, \& Clarke, 2003; López, Bocco, Mendoza, \& Duhau, 2001; Nassar, Blackburn, \& Whyatt, 2014). In the course of urbanization, large amount of agricultural land has been changed into built-up area or into other urban land uses and this complicated practice is intrinsically hard to control. The impacts of such kind of landscape change on the environment, resulting from urbanization are becoming more and more complex over time (Xiao et al., 2006). Urban sprawl, another major impact of urbanization, is a low-density and dispersed spatial pattern of urban growth with both environmental and social impacts is also causing a threat for irregular urban growth (Aguilera, Valenzuela, \& Botequilha-Leitão, 2011).

Urban expansion which is a form of urbanization and takes place in different ways such as in the form of increasing residential density, redevelopment of built-up areas, creating new urban lands that were previously non-urban and so on(Angel, Sheppard, \& Civco, 2005). But doing so, may cause encroachment of several natural green areas agricultural land, forest land, water areas etc. Urban expansion thus primarily results in conversion of land especially from natural to built-up areas. Consequences of urban expansion are not only limited for population but significantly affect environmental ecosystem in the form of water scarcity, deforestation, floods etc(Puertasa, Henríquez, \& Meza, 2014).

Another significant reason for extension of urban built-up is rapid population growth, industrial expansion and development of commercial activities that have been experienced in many developing areas like Bahawalpur. Such kind of development is occurring in an unplanned and haphazard manner mostly along new residential colonies. In view of the changes occurring in the pattern of economic activities, industrialization and urbanization, researchers argue that demographic change is the major driving force for urban expansion as more land is demanded by increasing population (Li, Sato, \& Zhu, 2003). Thus, it would not be invalid to say that in developing countries like Pakistan, rapid population increase is one of the major indicators of urban expansion and city growth. Population of low income and developing countries is increasing with the pace that is almost five times greater than that of developed countries (Nations, 2005). In Pakistan and in many other developing countries, irregular sprawling of cities at a very high rate is creating numerous social and economic problems of complex nature. Although, urban areas comprise a very small part of the world's land area but they contain $52 \%$ of the world's inhabitants (PRB, 2013) and their rapid expansion has caused rapid and threatening impact on natural environment (Grimm, Morgan Grove, Pickett, \& Redman, 2000; Haregeweyn, et al., 2012; He, Okada, Zhang, $\mathrm{Shi}, \& \mathrm{Li}, 2008)$. Consequently, many problems like increase in squatter settlements, deficiency of water, lack of sewerage facilities, overburdening of municipal services, and conversion of valuable farmland into non-farm uses are rising notably on the urban scene. Ever since, many big cities of our country specifically cities of Punjab including Bahawalpur are located in agricultural areas, urban expansion is, therefore, a constant threat to arable land and to future food supplies for rapidly augmenting population. Urbanization in Bahawalpur is characterized by several notable factors including natural population increase, migration from rural to urban areas, changes occurring in the settlement patterns, improvements in living standards of the people, changing socio-economic conditions etc.

In 1981, about 24 million people were residing in urban areas of Pakistan representing 28 per cent of country's total population. According to 1998 census, the urban population went up to 43.5 million sharing 32.5 percent of the country's total population (143 million). In 2010, total population of the country jumped to 173.5 million and the urban population reached to 63.1 million sharing 36.3 percent of the total population. It has been estimated that urban population may surpass 121 million by the year 2030 . The level of urbanization of 45.6 percent would then be the highest amongst the South East Asian countries (GOP, 2011).

Almost similar trends can be noted in Bahawalpur city where the study of previous years witnessed rapid growth of urban population and development of peri-urban areas. Because of increasing demands for housing facilities, conversion of farmland to residential structure has become most significant issue over the past few decades. Massive development of housing units has taken place during the last fifty years. For appraising the impact of rapid population growth on urban area expansion, the foremost objectives of the study were;

1. To look in to the population growth trends in Bahawalpur during last fifty years.

2. To work out the increasing urban expansion ratio with respect to previous and current urban areas.

3. To examine the impact of urban growth on changing land use pattern since last forty years.

However, this study is not an end in itself and further scientific and GIS based research is required to overcome the issue. In this connection, recently, in 2014 urban unit of the government of Punjab has started an extensive survey of Bahawalpur city. The foremost objective of this survey is to provide base-line information that can be used for future planning of the city. Several other such surveys and studies may appear on the scene in future. 


\section{Study Area and Methodology}

This section, very briefly, tells the methodology used to meet up the objectives of the study and starts from the short introduction of the region where study area, Bahawalpur city, is located (figure 1). Bahawalpur region comprises of former Bahawalpur State which was merged in the Province of West Pakistan on $14^{\text {th }}$ of October, 1955. On disintegration of One Unit in 1969, the territory comprising the former Bahawalpur State became an Administrative Division of the Punjab Province with Bahawalpur city as its headquarter. The region, Bahawalpur division, consists of three districts, namely, Bahawalpur, Bahawalnagar and Rahim Yar Khan, covering an area of 45,588 sq km (Javaid, 2009). Bahawalpur spreads over an area of 24,830 sq km and shares $54.5 \%$, Bahawalnagar spreads over an area of 8878 sq km and shares $19.5 \%$, and Rahim Yar Khan spreads over an area of $11880 \mathrm{sq} \mathrm{km}$ and shares $26 \%$ of the total area of the region.

Bahawalpur is the biggest district of Punjab with regard to the size of geographic area havingsix Tehsils namely Bahawalpur city, Bahawalpur Sadar, Ahmad Pur East, Yazman (area wise biggest tehsil of the Punjab province), Khairpur Tamewali, and Hasilpur (Khalid \& Gilani, 2010).
The focus area of research is Bahawalpur city which is located on the northern fringe of Bahawalpur District of the Punjab province of Pakistan. Its location place is geographically a transitional zone along south eastern bank of Sutlej river between green agricultural land on the north and hot arid desert on the south. Bahawalpur is one of the highly urbanized cities of Pakistan currently occupying a total area of 11500 acres within Municipal limits. The city is a divisional, district and tehsil headquarter. The foundation of the city was laid down by Nawab (ruler) Amir Bahawal Khan in 1774 AD. Until 1940's it remained confined within walls, having characteristics of medieval type of city (GOP, 1974).Currently it consists of Municipal and Cantonment areas. Municipal area is administered by Tehsil Municipal administration and cantonment area is administered by Cantonment Board.

Temporal view indicates that Bahawalpur city was once a small village named SodhaJhoke and Bahamanabad (Bahawalpur Outline Development Plan, 1974). Journey from a small village to a big city had lasted over almost three centuries. High increase in urban population had been correlated with natural increase and migration from rural to urban areas.

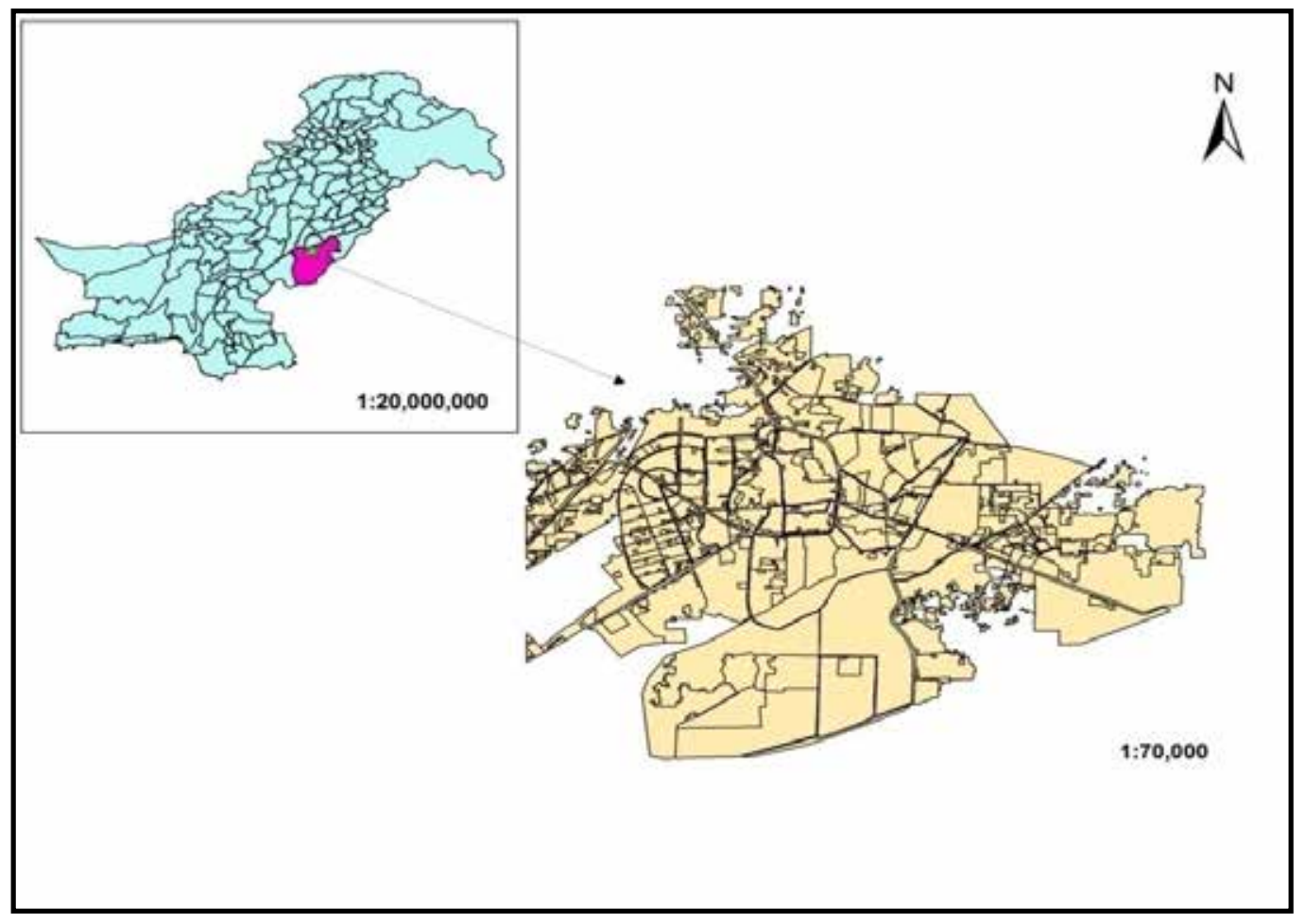

Figure 1. Location of Bahawalpur City in Punjab 
The research aims to analyze the population growth and urban expansion over past 62 years in the city from 1950 to 2012. Urban expansion rate and land consumption per capita are calculated by taking census years as standard for measuring the urban expansion land consumption ratio per capita in different time periods ( 1951-61, 1961-72, 1972-1981, 1981-1998 and 1998- 2012) using the equation 1 and equation 2 respectively (Haregeweyn, et al., 2012; Xiao, et al., 2006; Xu \& Min, 2013).

$$
U E=\frac{U A(i+n)-U A(i)}{n \times U A(i)} \times 100 \quad \text { Equation } 1
$$

Where; UA $(\mathrm{i}+\mathrm{n})=$ Urban area in hectares at time $\mathrm{i}+\mathrm{n}$

UA (i) = Urban area in hectares at time i

and $\mathrm{n}=$ Time interval of calculating period in years

$$
L C R=\frac{U A}{P}
$$

Equation 2

Where; $\mathrm{LCR}=$ Land consumption ratio

$$
\begin{gathered}
\mathrm{UA}=\text { Urban area of city } \\
\text { and } \mathrm{P}=\text { Total population of city }
\end{gathered}
$$

The extent of city expansion is measured by overlaying theurban areas of 1970, 1990 and 2012. The analysis is also based upon secondary data collected from official administrative departments including Cantonment Board of Bahawalpur (CBB), Tehsil Municipal Administration (TMA) of Bahawalpur city. Base maps are taken from outline development plans of Bahawalpur city for the years 1974, 1993 and 2012 which were then digitized using GIS software ArcGIS9.3. The expansion of city has been analyzed by superimposing these time series maps and calculating respective urban area with the help of GIS techniques. Statistics taken from outline development plans and Tehsil Municipal Administration (TMA) of Bahawalpur city also verifies the horizontal expansion of city. Data about periodical change in urban population growth and spatial change have been derived from different sources including District Census Reports (DCRs) of 1951,1961,1972,1981 and 1998, records of Cantonment Board of Bahawalpur (CBB), Tehsil Municipal Administration of Bahawalpur City, Punjab Development Statistics (2012) and Bahawalpur Outline Development Plans of 1974 and 1993. To meet up the objectives of the study, all the collected data and concerned information were then put together for final treatment using integrated approach supported by temporal, spatial, GIS, statistical and quantitative methods.

\section{Results and Discussion}

\subsection{Temporal View of Population Growth in Bahawalpur City}

The population growth trends of Bahawalpur city reflect urban expansion with significant fluctuations linked with land use change and increase in built-up area. After the city foundation in 1748, it experienced very slow urban population growth. In 1881, population of the city was only 13,635 and reached to 18,716 in 1891. But after this period a significant decline has been observed in the population growth rate of the city. After passing 40 years in 1931, population of the city reached over 20,943 persons with the addition of only 2,000 persons (table 1 and figure 2).

Various reasons of this slow growth have been reported in the literature including low natural increase, infrequent immigration and spreading of various contagious diseases like plague. Among the chief geographic reasons were harsher climatic conditions, severe aridity, fewer resource opportunities, poor desert soils, low agricultural produce and in turn low carrying capacity of the region. In spite of the fact that immigration was encouraged and to attract the people from other areas, incentives like free acquisition of land were offered to them, they were not willing to work on lands in hard and harsher geographic conditions. Consequently, population density in the region remained low and growth of cities proceeded at a very slow pace. Furthermore, it was the time when most of the population lived in rural areas with poor life style and unhygienic conditions, and high mortality rate in the city. Bahawalpur city of this time period is considered as the city of colonial times ruled by Abbasids Nawabs. The main settlement and center of activities of Nawabs (The royal noblemen of Abbasid dynasty ruled on Bahawalpur) was Dera Nawab Sahib located a distance of about $60 \mathrm{~km}$ west of Bahawalpur in Ahmedpur east tehsil.

In the decade of 1930s, a number of new development projects, like Sutlej Valley Project (1925), were started by local Nawab with the help of British planners to bring prosperity in the region and boost local agriculture. Such kind of projects and developmental works had brought massive changes in land use pattern and population growth. As a result, population of the city jumped from 20,943 in 1931 to 40,015 in the year of 1941 and became double within 10 years. Afterwards, a second major fall was observed in population from the year 1941 to 1951 with the addition of only 1500 persons in ten years. It was the decade of Pakistan's independence (14, August, 1947) when massive migration from both sides of borders occurred and large number of Hindus who were settled in this region migrated to India. This was the last significant fall in population of this region that had been ever observed.

After the independence, first census of Pakistan was conducted in 1951 and then second in 1961 which reported 84,377 persons living in the Bahawalpur region. This was the period of population explosion in the region and afterwards population of the region increased progressively. The growth rate of the population during this time period was higher to over 10\% (PCO, 1961). During this period the inter-city and inter-district migration played an important role in fast increase of population and many people migrated and settled in Bahawalpur region. Besides, in 1955 Bahawalpur State was merged into one unit and a division of military was 
settled here. Many rehabilitation schemes were launched and implemented during this period of time. These factors, not only caused high population growth, but also the total area of city was extended outward and became double bringing many changes in the existing land use of the city. In 1972, the population of the city jumped to become 135,263 persons with an increase of 48,000 individuals. In 1981, the population of the city reached to 180,263 people. Afterwards, in 1998, the population of the city reached to 408,305 persons with an increment of further 228,042 people. The growth occurred at a very striking annual rate of nearly 5\% (PCO, 1999)during the period of 17 years. This was the period of highest increase in population in the history of
Bahawalpur. Currently Bahawalpur is twelfth biggest and one of the fastest growing cities of Pakistan. Its population is increasing rapidly due to high fertility rate as well as due to high rural to urban migration rate. Besides other services, the availability of educational facilities is its big attraction for immigrants. On the basis of dominating functions, presently it can be named as educational city. The inhabitants of rural areas who are cognizant of the significance of children education prefer to migrate and settle in Bahawalpur. In this way the city is progressing day and night in terms of population size and consequently its land use pattern is changing.

Table 1. Year wise population of Bahawalpur city

\begin{tabular}{cccc}
\hline Year & Population & Population Change (persons) & Growth Rate (\%) \\
\hline 1881 & 13,635 & - & - \\
\hline 1891 & 18,716 & 5,081 & - \\
\hline 1901 & 18,546 & -170 & - \\
\hline 1911 & 18,414 & -132 & 0.07 \\
\hline 1921 & 18,494 & 80 & 0.04 \\
\hline 1931 & 20,943 & 2,529 & 1.3 \\
\hline 1941 & 40,015 & 19,072 & 9.1 \\
\hline 1951 & 41,646 & 1,631 & 0.4 \\
\hline 1961 & 87,377 & 45,731 & 10.2 \\
\hline 1972 & 135,263 & 47,886 & 5.5 \\
\hline 1981 & 180,263 & 45,000 & 4.93 \\
\hline 1998 & 408,305 & 228,042 & 4.93 \\
\hline 2009 (est.) & 507,228 & 98,923 & 2.97 \\
2012 (est.) & 560,588 & 53,360 & 3.08 \\
\hline
\end{tabular}

Source: (PCO, 1951, 1961, 1972, 1981, 1999)(PDS, 2012)

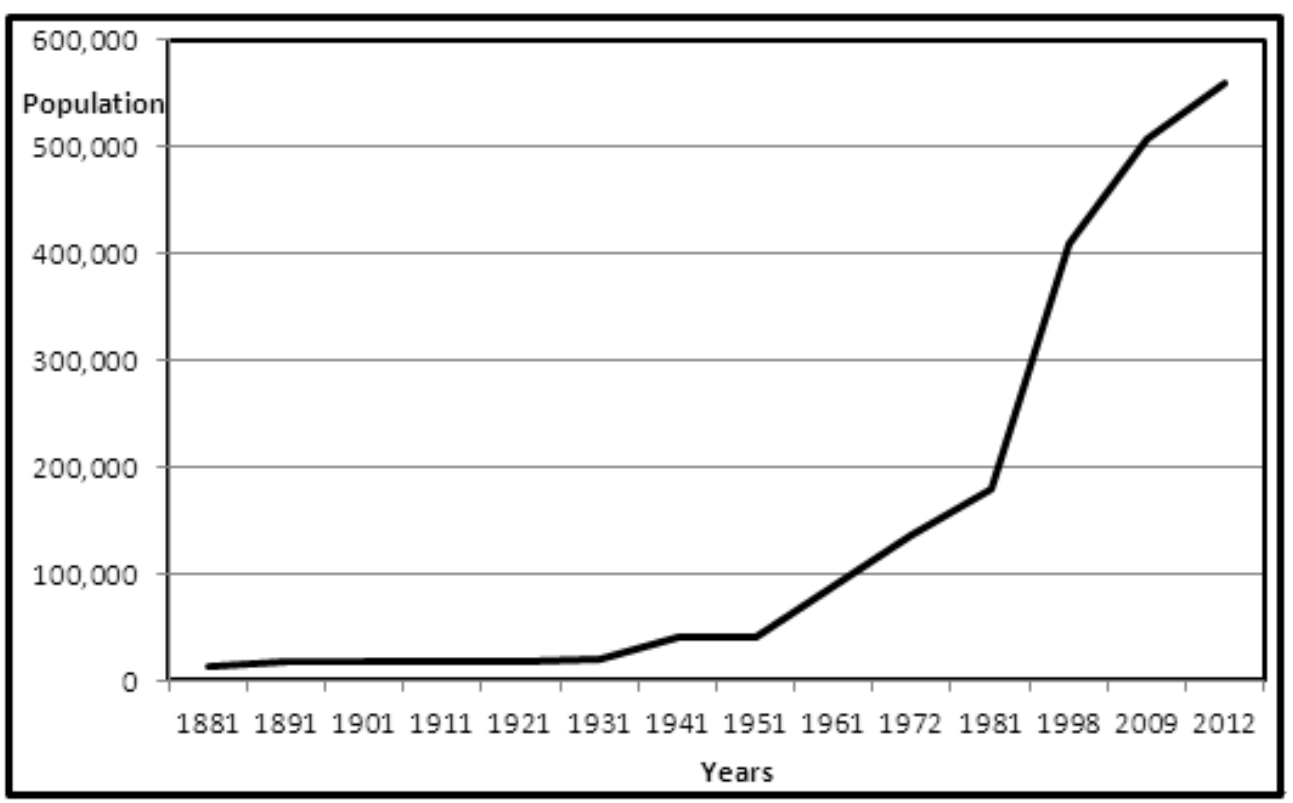

Source: (PCO, 1951, 1961, 1972, 1981, 1999; PDS, 2012)

Figure 2. Historical population growth of Bahawalpur region 
At the present, city is passing through a phase of residential, educational and commercial development. According to 2009 estimates of Tehsil Municipal Administration Bahawalpur city, the population reached to 507,228 adding further 98,923 souls to the city’s population. The population of Bahawalpur city has reached to 560,588 in 2012 (PDS, 2012) adding 53,360 people within short period of time of three years. This depicts substantial increase in the population at a growth rate of over $3.08 \%$ per annum and the emergence of Bahawalpur as an important administrative, educational, health, recreational and trade centre in the region.

\subsection{Spatial Expansion of Urban Bahawalpur}

The ultimate effect of rapid population growth resulted very fast spatial expansion of the city.

\subsubsection{Urban Expansion from 1950 to 1970}

Up to 1950, city was confined within a wall and called as walled city that had the total area of about 590 acres (Bahawalpur Outline Development Plan, 1974) and controlled by Baghdad-ul-Jadeed Improvement Trust established by local Nawabin 1954 (TMA Bahawalpur City, 2011). Under this trust about 10 colonies were approved and constructed for local public and officials in Model town B (Single story bungalow scheme, Double story bungalow scheme, Labor colony, Peon colony etc.). Majority of these colonies occupied productive agricultural land and covered considerable land area. From 1947 to 1955 many rehabilitation schemes were launched due to Pakistan independence and as a consequence many residential schemes were initiated and developed including Model town B, Muhajir colony and Shahdra. Model Town A was also built in 1953 for high government officials and one unit staff colony for the residence of government servants.

Urban area of the city expanded out side from central walled locality to peripheries and reached to 4287 acres in 1972. Land use pattern developed into $46 \%$ residential, $1.7 \%$ commercial, $8.3 \%$ educational, $2.3 \%$ industrial, $2 \%$ graveyard, $4.2 \%$ public buildings, and $3.6 \%$ parks or open spaces. Agriculture area of the city expanded to $31 \%$. However, to meet up the demands of city's growing population major developments took place in educational and residential sectors (table 2 and figure 3 ).

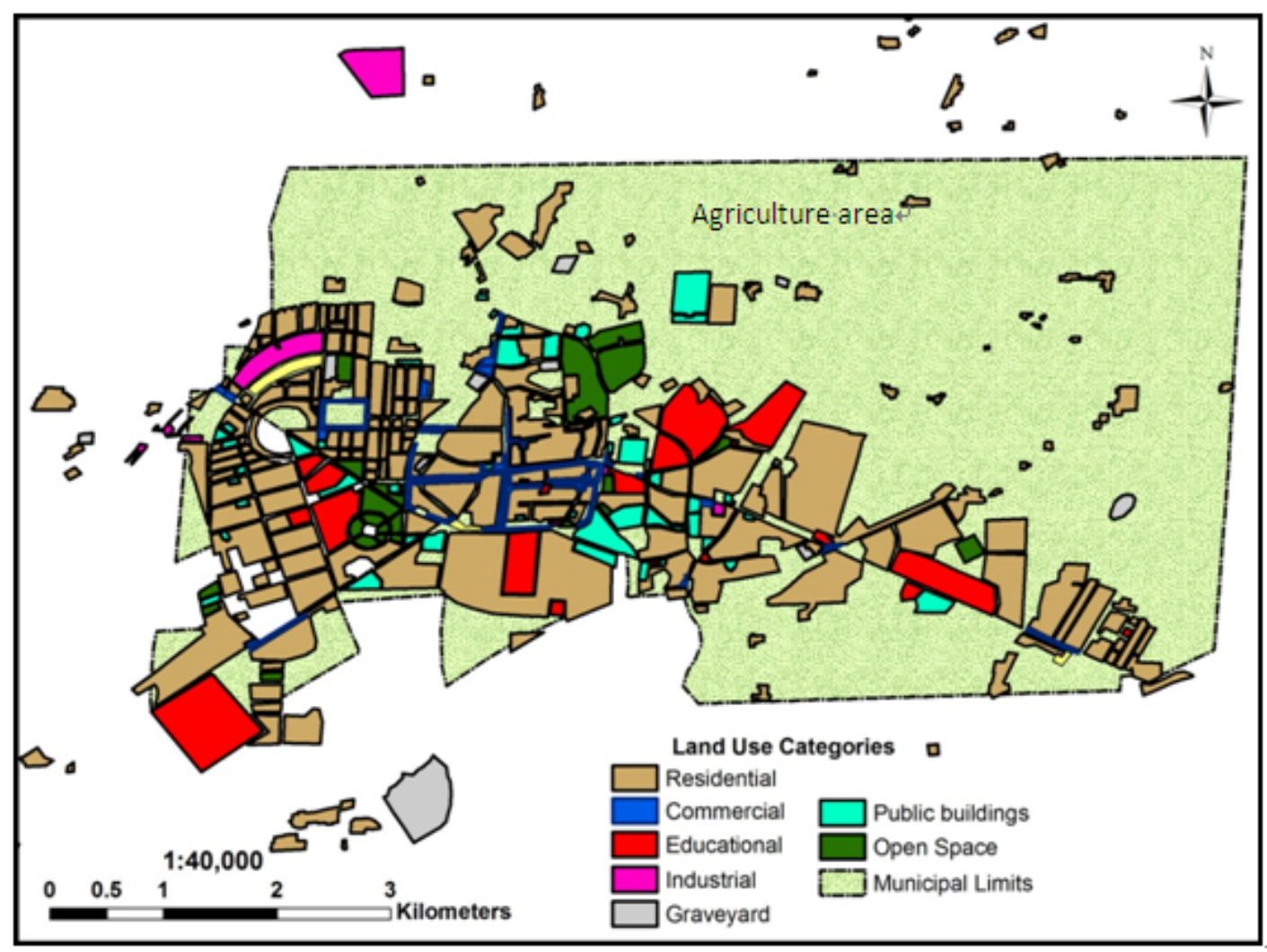

Figure 3. Land use pattern of Bahawalpur City (1972) 


\subsubsection{Urban Expansion from 1970 to 2012}

According to first development plan of Bahawalpur city (GOP, 1974), area of the city in 1974 was about 4,308.4 acres. Later on, in 2002 Municipal Corporation was renamed again and converted in to Tehsil Municipal Administration (TMA) Bahawalpur City. The whole administrative system was modified and replaced by new rules and laws. These rules permitted the farmland owners to build residential colonies on their lands by paying a fix fee for the purpose of approving scheme plan and claiming certain facilities like gas, electricity, sewerage etc. After this, a massive change was observed in the form of areal expansion of the city that accelerated the rate of farmland conversion into built-up area and urban area of city reached to 5609 acres in 1980, and 7731 acres in 1998 (table 2). Residential area increased to $51 \%$ with same proportion of commercial area $(1.7 \%)$ as it was in 1972.

Table 2. Land Use pattern of city in different years

\begin{tabular}{lcccccc}
\hline Land use & $\begin{array}{c}\text { Area in acres } \\
(1972)\end{array}$ & \% age & $\begin{array}{c}\text { Area in acres } \\
(1998)\end{array}$ & \% age & $\begin{array}{c}\text { Area in acres } \\
(2012)\end{array}$ & \% age \\
\hline Residential & 1975 & 46 & 3930 & 51 & 6617 & 57 \\
\hline Commercial & 75 & 1.7 & 131 & 1.7 & 304 & 2.6 \\
\hline Educational & 356 & 8.3 & 294 & 3.8 & 479 & 4.1 \\
\hline Open Space & - & & - & - & 423 & 3.6 \\
\hline Institutional / Offices & 184 & 4.2 & 396 & 5.1 & 240 & 2.1 \\
\hline Burial Grounds & 90 & 2 & 28 & 0.36 & 103 & 0.9 \\
\hline Industrial & 99 & 2.3 & 98 & 1.2 & 44 & 0.3 \\
\hline Parks & 155 & 3.6 & 155 & 2 & 367 & 3.1 \\
\hline Health & 32 & 0.7 & 41 & 0.5 & 120 & 1.5 \\
\hline Religious & 19 & 0.5 & 19 & 0.2 & 50 & 0.4 \\
\hline Agriculture & 1302 & 31 & 2639 & 34 & 2589 & 22 \\
\hline Total & 4287 & & 7731 & & 11500 & \\
\hline
\end{tabular}

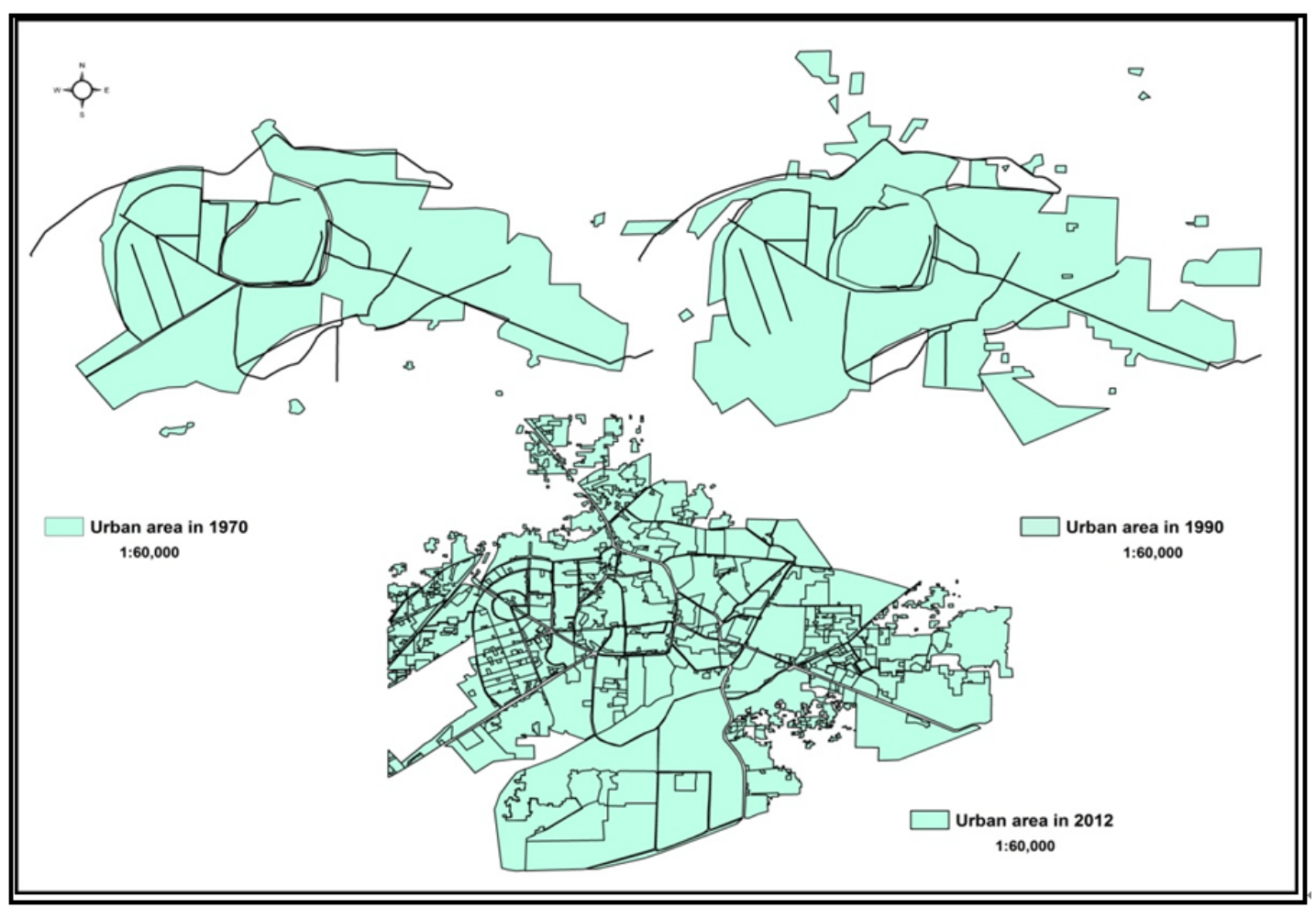

Figure 4. Urban area expansion from 1970 to 2012 


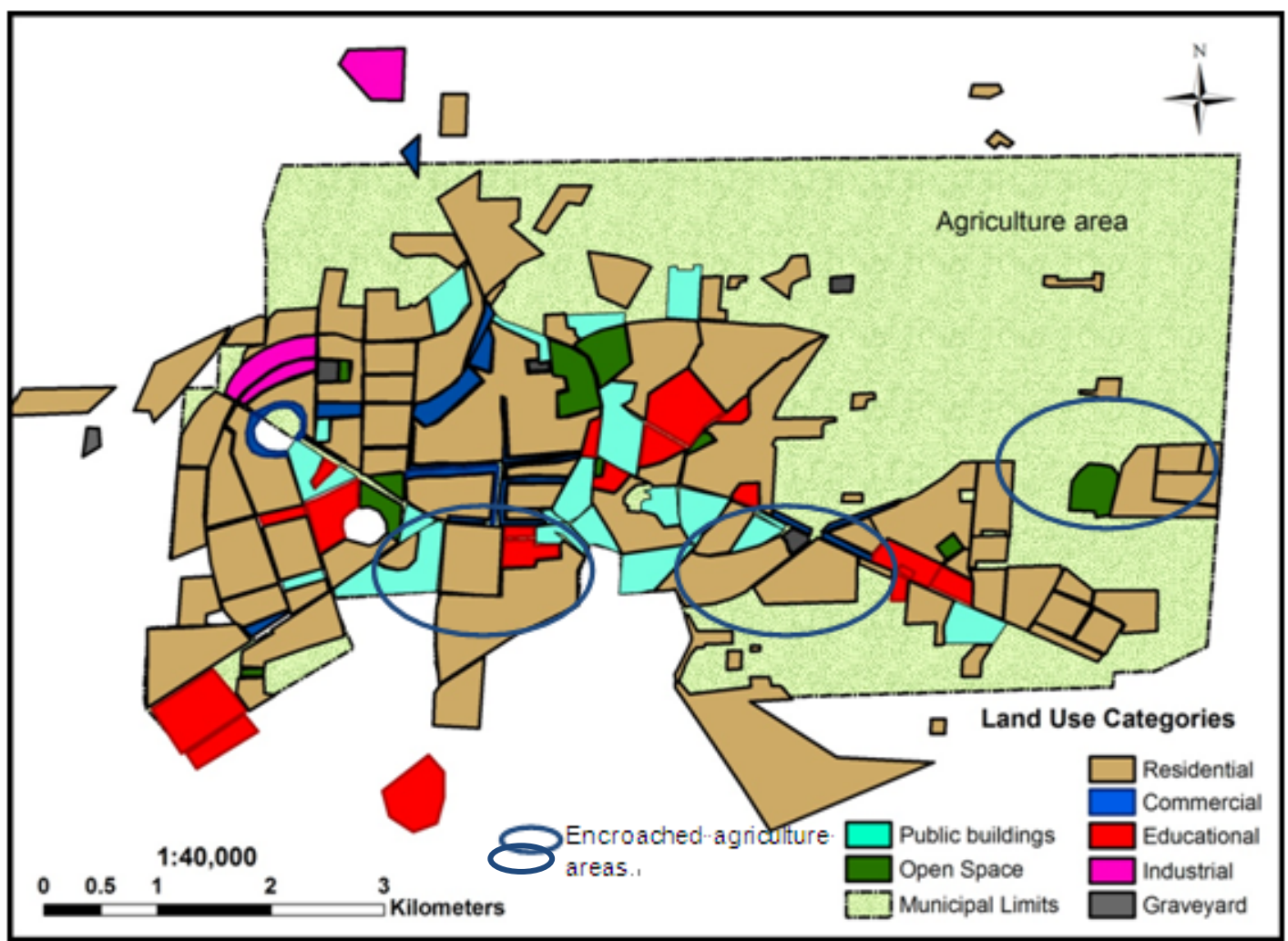

Figure 5. Land use pattern of Bahawalpur City (1998)

Such a considerable increase in urban area of the city engulfed outlying agricultural lands. Some parts of the city which are currently densely populated like southern and south western areas (including Medical colony, Trust colony, Muhamdia colony, Hashmi garden), were once occupied mainly by agricultural land. Now, all they have been converted into urban built-up land (figure 5).

According to current surveys and studies conducted by TMA city, spatial expansion of city in all directions is occurring at a fastest rate and city area has reached to 11500 acres with more than 6000 acres residential development making $57 \%$ of total built-up area. The main reason for increasing urban area and residential expansion is migration of people from nearby rural areas to the city for the sake of education and employment. Land use pattern in 2012 has become more fragmented and expanded due to residential sector growth in the form of planned residential colonies and towns. Commercial area that was confined within walled city became spatially distributed along other residential sectors and regional roads. City development took place in the form of new commercial plazas and centers which not only created more employment opportunities but has become a major indicator for making Bahawalpur as one of highly urbanized cities of Pakistan. Currently commercial area is sharing $2.7 \%$ of total urban area of city and expanding more in the peripheries. Many new land use classes have been added and segmented like parks and open spaces are classified separately. A comprehensive land use pattern of Bahawalpur city for the year 2012 has been shown in figure 6 which reveals some newly scattered built-up polygons and reflects that currently city is at the stage of urban sprawl. On northern and north western side city limits have been reached up to Sutlej river which is a physical barrier and also forms the district boundary. With this exception, city is irregularly expanding in almost all directions. The concerned departments and city management has recently realized the problems which are originating due to this type of expansion and the recent land use, and socio-economic survey of the city which may be complete by the end of this year is an example in this regard.

Land use comparison for three time spans shows constant commercial area from 1972 to 1998 making $1.7 \%$ of total urban area which increased to above 300 acres in 2012 making $2.6 \%$ of total urban area. Moreover, rise in educational, health and religious area is also observed. Proportion of open spaces also increased from 155 acres in 1970 's to above 360 acres in 2012. A great fall in industrial area observed, from 99 acres in 1972 to only 44 acres remained in 2012 due to expanding residential development (table 2 and figure 7). 


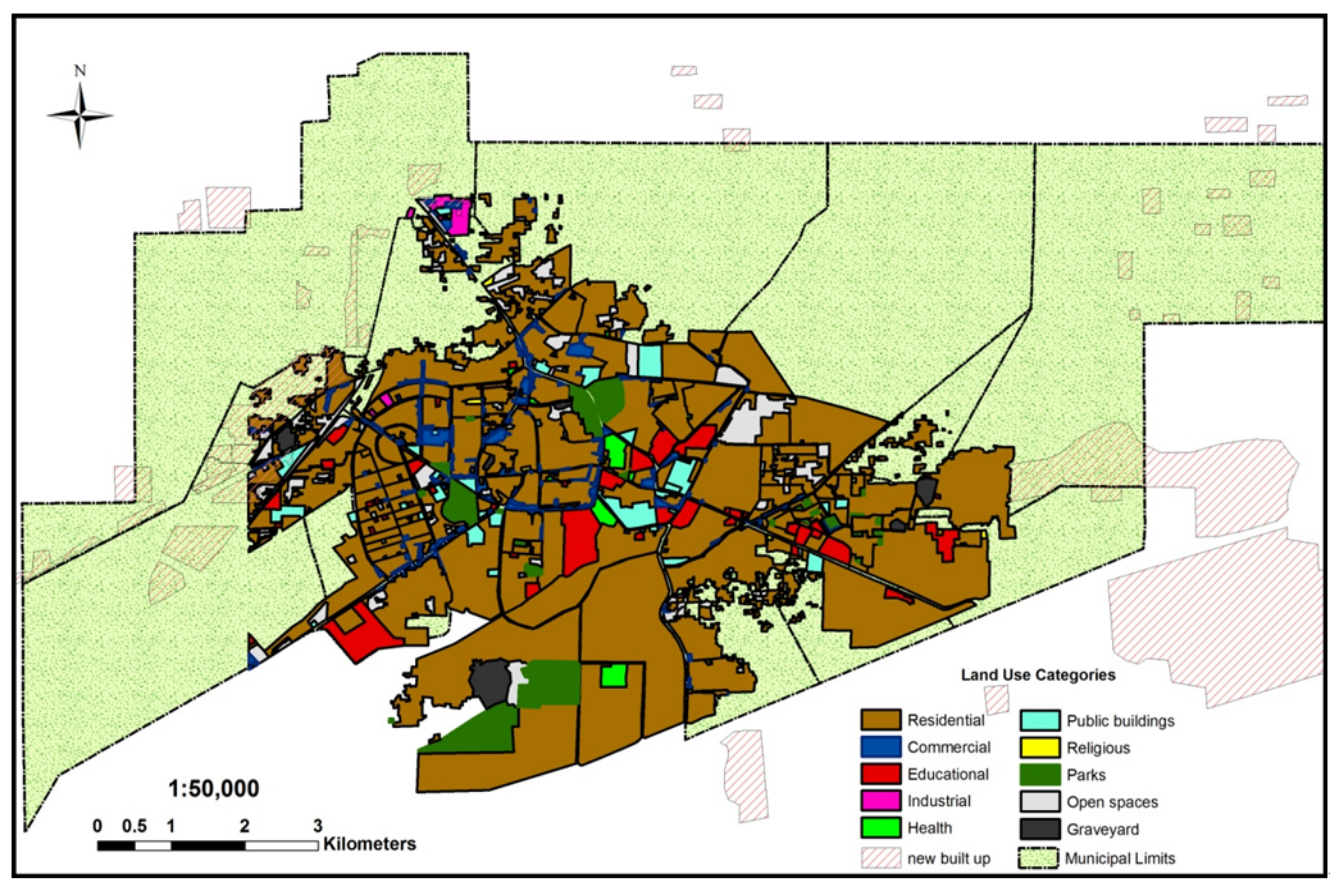

Figure 6. Land use pattern of Bahawalpur city (2012)

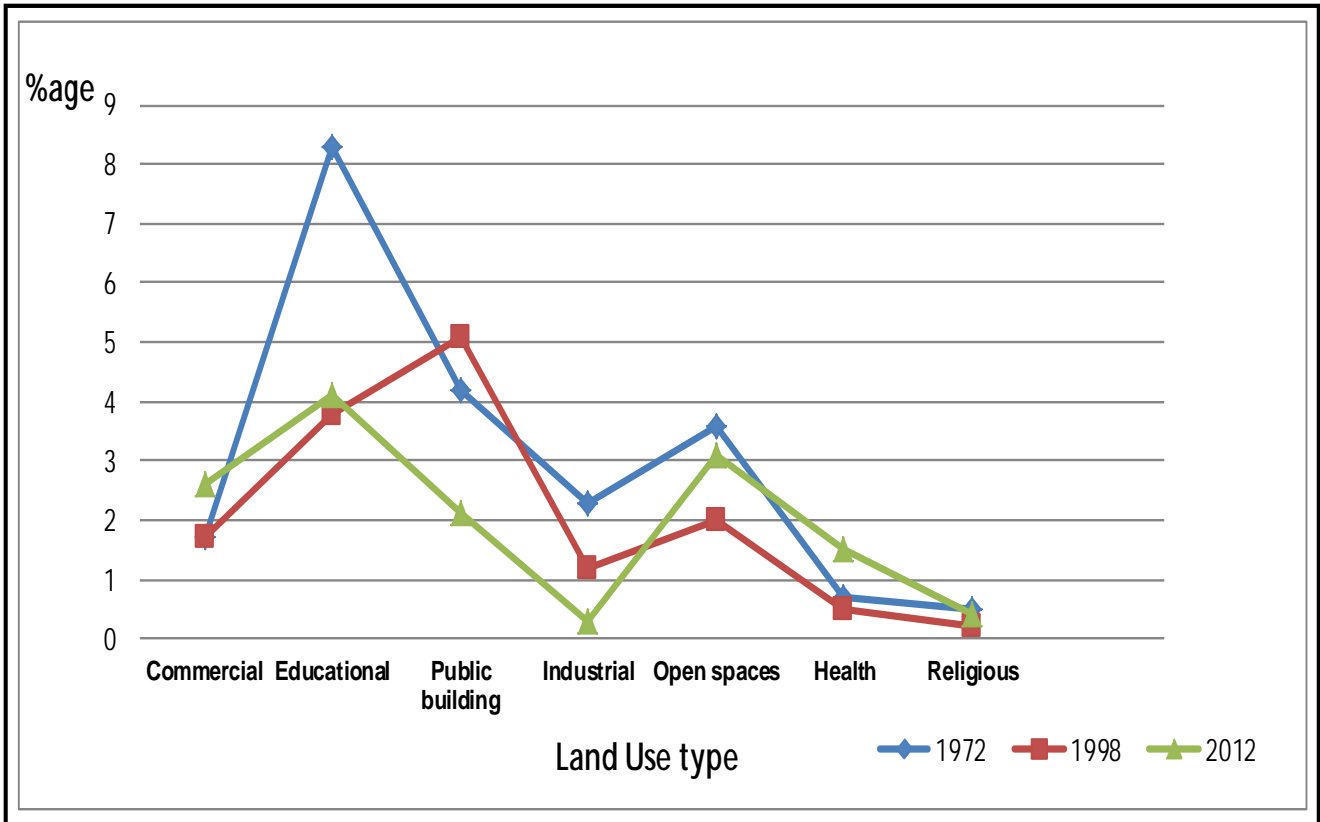

Figure 7. Percent change in different land use patterns of city in three decades 


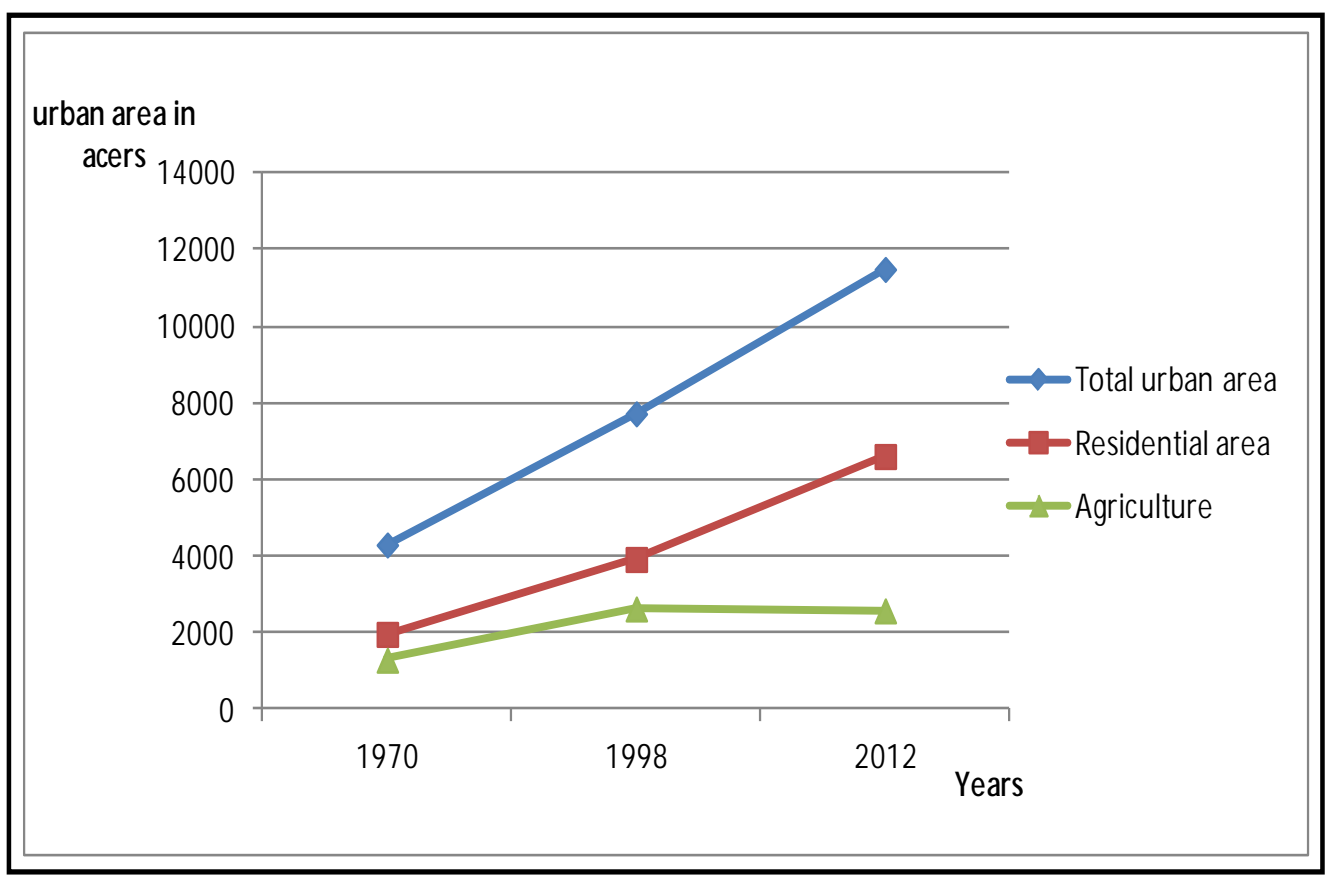

Figure 8. A comparison of total urban, residential and agriculture area

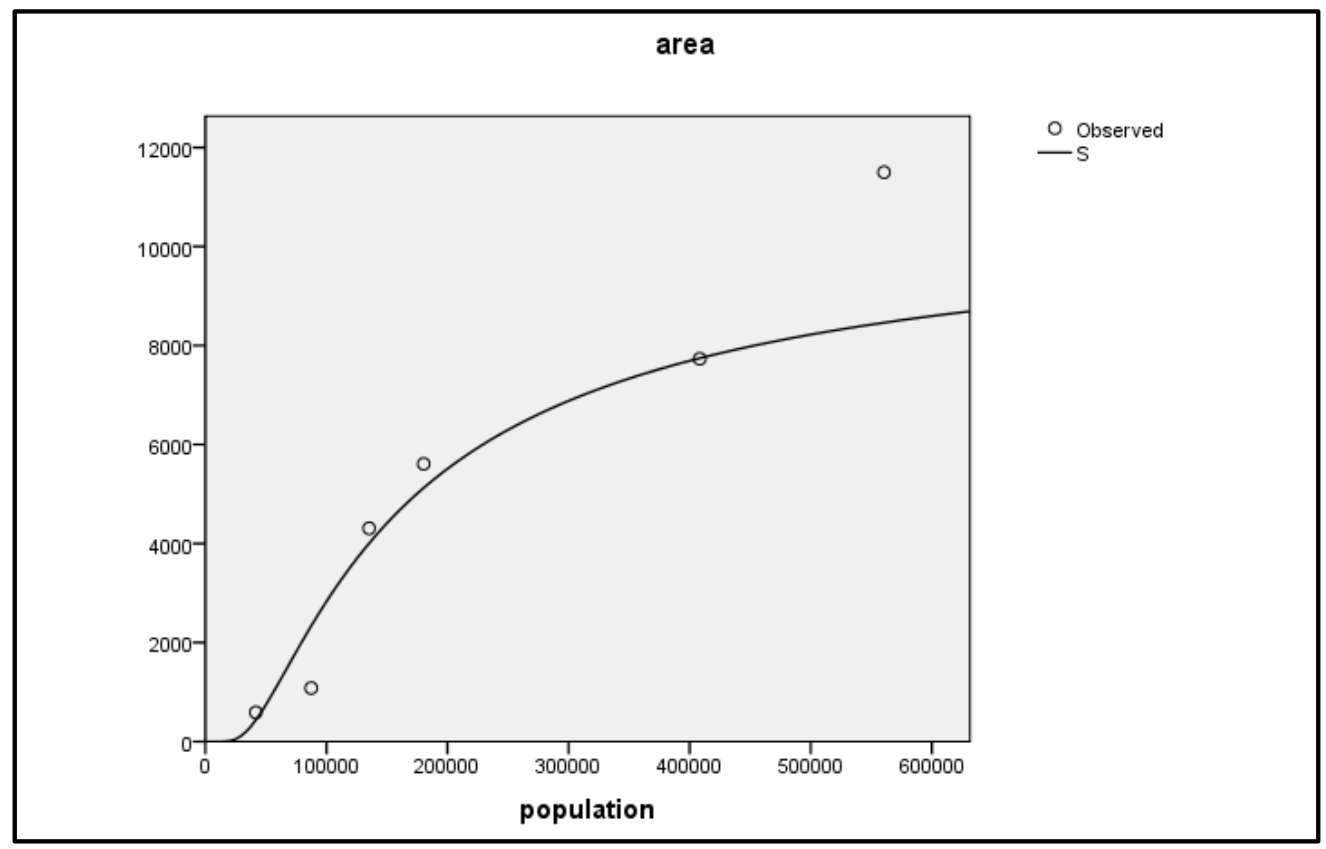

Figure 9. Regression curveof population and urban area

Table 3. Urban expansion and land consumption ratio from 1951 to 2012

\begin{tabular}{|c|c|c|c|c|c|c|c|c|c|c|c|}
\hline \multirow{2}{*}{ Years } & \multirow{2}{*}{1951} & \multirow{2}{*}{1961} & \multirow{2}{*}{1972} & \multirow{2}{*}{1981} & \multirow{2}{*}{1998} & \multirow{2}{*}{2012} & \multicolumn{5}{|c|}{ Urban change ( in percentage) } \\
\hline & & & & & & & 1951-1961 & 1961-1972 & 1972-1981 & 1981-1998 & 1998-2012 \\
\hline Population & 41646 & 87377 & 135263 & 180263 & 408305 & 560588 & & & & & \\
\hline $\begin{array}{c}\text { Urban } \\
\text { area } \\
\text { (acres) }\end{array}$ & 590 & 1081 & 4308 & 5609 & 7731 & 11500 & $8.32 \%$ & $27 \%$ & $3.5 \%$ & $2.25 \%$ & $3.5 \%$ \\
\hline $\begin{array}{l}\mathrm{LCR}= \\
\mathrm{UA} / \mathrm{P}\end{array}$ & 0.01 & 0.01 & 0.03 & 0.03 & 0.01 & 0.01 & & & & & \\
\hline
\end{tabular}


Urban area analysis for 40 years shows a steep rise of total urban area of the city from 4287 acre to 11500 acre in 2012 showing a progressive trend of urbanization of the Bahawalpur city. Increasing residential expansion is a major reason of fall in agriculture area. Residential area again dominated and increased from 1975 acres in 1972 making $46 \%$ of total urban area to 6617 acres making $57 \%$ of total urban area in 2012. Agricultural area increased to some extent from 1302 acres in 1972 to 2639 acre in 1998 due to the delimitation of urban boundaries which started to fall again and went down to 2589 acres in 2012 (figure 8). This very scant amount of land is allocated for growing forage crops and for plant nurseries within the city. At the same time, area occupied by roads and industries shows significant increase that is closely linked with development of economic activities and growth of the city. The area consumed by public places, buildings and educational institutes etc. also increased considerably.

Furthermore, the study tells that municipal limits also expanded during 1970 to 2012 to accommodate increasing population pressure and compensate decline in agricultural land in the city (figure 4). Residential expansion ratio calculated for the period from 1972 to 1998 shows 3.8\% rise in 26 years, whereas from 1998 to 2012 it shows 4.8\% rise in just 14 years. In short, all this shows a progressive rise in residential area during 40 years of city's urban growth.

Urban expansion can be computed as presented in table 3. From the years 1951 to 1961,1961 to 1972,1972 to 1981 , 1981 to 1998 , and 1998 to 2012, urban area increased to $8.3 \%, 27 \%, 3.5 \%, 2.2 \%$ and $3.5 \%$ respectively. Similarly, land consumption ratio also showed a constant value of 0.01 in 1951 and 1961, than became 0.03 in 1972 and 1981 again becoming 0.01 in 1998 and 2012. It verifies the significant urban area expansion from 1970 to 2012 (figure 4). The regression curve that best fits describes the relationship between population and urban area (with $\alpha=0.005$ and $\mathrm{r}^{2}=$ 0.885 ) is $\mathrm{S}$ curve or sigmoid curve which equates as;

$$
\begin{gathered}
\ln (\mathrm{Y})=\mathrm{b} 0+(\mathrm{b} 1 / \mathrm{t}) \\
\ln (\mathrm{Y})=9.281+(-133341.348)(1 / \mathrm{X})
\end{gathered}
$$

The curve shows that estimated maximum urban area expansion can limit to 8593 acres if population reaches to 6000,000 . Regression analysis also reveals that from the year 1951 to 1961 there is a slow rise in urban population with increasing urban area. Afterwards, from 1971 to 1998 population and urban area grows rapidly reaching to above 4 million persons and above 7000 acres in terms of area (figure 9). The current values of urban population show a stationary trend with low rise in population but city has reached to its maximum limits of urban expansion in terms of area making an outlier of 11500 acres as shown in figure 9 .

\section{Conclusions}

The study concludes that there is a significant increase in urban area that has reached from 590 acres in 1951 to 11500 acres in 2012. This happened due to rapid increase in population which reached from 41646 in 1951 to 560588 in 1912. It revealed that urban area expansion in the past reached at its apex during the period of 1960 to 1970 . Afterwards, a steady rise has been observed with almost same land consumption ratio. At the moment, city is expanding in almost all directions with a significantly faster pace than ever before. Population is increasing and developments are taking place within and outside the city limits in the form of roads (constructing and widening), residential built up, commercial rise and industrial expansion. The journey of Bahawalpur starting from a small town of the state to a large city brought about many notable changes in its land use pattern. Urban expansion is taking place in almost all directions particularly along the regional roads. Currently, northern and north eastern part of the city is rapidly converting into residential colonies. According to TMA records, 53 residential housing schemes have been developed in the city within last 10 years that have consumed several hundred acres of farmland. New residential structures are increasing and de-shaping the morphological pattern of the city. This reflects the saturation of city in terms of built up area and currently it has reached at the stage of urban sprawl. More than 25 Katchi Abadies (squatters) are also contributing in urban sprawl. Resultantly, the services provided by local government and municipal authorities are now facing many challenges. Particularly the services related to solid waste and waste water management, water supply distribution, intra-city transportation management etc. are under a serious stress. This reflects alarming situation for local government and urban planners. Effective planning and proper management of the city systems is essential need of the time otherwise urban problems may aggravate further in near future.

\section{REFERENCES}

[1] Aguilera, F., Valenzuela, L. M., \& Botequilha-Leitão, A. (2011). Landscape metrics in the analysis of urban land use patterns: A case study in a Spanish metropolitan area. Landscape and Urban Planning, 99(3-4), 226-238. doi: http://dx.doi.org/10.1016/ j.landurbplan.2010.10.004

[2] Aljoufie, M., Zuidgeest, M., Brussel, M., \& van Maarseveen, M. (2013). Spatial-temporal analysis of urban growth and transportation in Jeddah City, Saudi Arabia. Cities, 31(0), 57-68. doi: http://dx.doi.org/10.1016/j.cities.2012.04.008

[3] Angel, S., Sheppard, S. C., \& Civco, D. L. (2005). Dynamics of global urban expansion. Washington DC: World Bank.

[4] Briassoulis, H. (2000). Factors influencing Land Use and Land Cover Change Encyclopedia of Life Support System, EOLSS (Vol. 1, pp. 1-9).

[5] Buhaug, H., \& Urdal, H. (2013). An urbanization bomb? Population growth and social disorder in cities. Global Enviornmental change, 23, 1-10. 
[6] Carole L.Jolly, \& Barbara Boyle Torrey (Eds.). (1993). Population and Land Use in Developing Countries: Report of a Workshop: NATIONAL ACADEMY PRESS Washington, D.C.

[7] Cheng, J., \& Masser, I. (2003). Urban growth pattern modeling: a case study of Wuhan city, PR China. Landscape and urban planning, 62(4), 199-217. doi:http://dx.doi.org/10 .1016/S0169-2046(02)00150-0

[8] GOP. (1974). Bahawalpur Outline Development Plan: 1974-1990. Lahore: Government of Punjab: Housing and Physical Planning Department.

[9] GOP. (2011). Task Force Report on Urban Development: Planning Commission, Government of Pakistan.

[10] Grimm, N. B., Morgan Grove, J., Pickett, S. T., \& Redman, C. L. (2000). Integrated Approaches to Long-TermStudies of Urban Ecological Systems: Urban ecological systems present multiple challenges to ecologists-pervasive human impact and extreme heterogeneity of cities, and the need to integrate social and ecological approaches, concepts, and theory. BioScience, 50(7), 571-584.

[11] Halder, J. C. (2013). Land Use/Land Cover and Change Detection Mapping in Binpur-II Block, Paschim Medinipur District, West Bengal: A Remote Sensing and GIS Perspective. IOSR Journal Of Humanities And Social Science $8(5), 20-31$.

[12] Haregeweyn, N., Fikadub, G., Tsunekawa, A., \& Tsubo, M. (2012). The dynamics of urban expansion and its impacts on land use/land cover change and small-scale farmers living near the urban fringe: A case study of Bahir Dar, Ethiopia. Landscape and Urban Planning, 106, 149-157.

[13] He, C., Okada, N., Zhang, Q., Shi, P., \& Li, J. (2008). Modelling dynamic urban expansion processes incorporating a potential model with cellular automata. Landscape and urban planning, 86(1), 79-91.

[14] Herold, M., Goldstein, N. C., \& Clarke, K. C. (2003). The spatio temporal form of urban growth: measurement, analysis and modeling. Remote sensing of Environment, 86(3), 286-302.

[15] Javaid, U. (2009). Bahawalpur State: Effective indirect participation in Pakistan movement. Journal of research society Pakistan, 46(2), 191-201.

[16] Khalid, S., \& Gilani, A. H. (2010). Distinctive Cultural and Geographical Legacy of Bahawalpur. Pakistaniaat: A Journal of Pakistan Studies, 2(2), 1-17.

[17] Li, L., Sato, Y., \& Zhu, H. (2003). Simulating spatial urban expansion based on a physical process. Landscape and urban planning, 64(1), 67-76.

[18] López, E., Bocco, G., Mendoza, M., \& Duhau, E. (2001). Predicting land-cover and land-use change in the urban fringe: A case in Morelia city, Mexico. Landscape and Urban Planning, 55(4), 271-285. doi: http://dx.doi.org/10.1016/S01 69-2046(01)00160-8

[19] Nassar, A. K., Blackburn, G. A., \& Whyatt, J. D. (2014). Developing the desert: The pace and process of urban growth in Dubai. Computers, Environment and Urban Systems, 45, $50-62$.

[20] Nations, U. (2005). World Urbanization Prospects: The 2005
Revision. New York: Department of Economic and Social Affairs: Population Division.

[21] PCO. (1951). 1st Population and Housing census survey; District Census Report of Bahawalpur: Pakistan Census Organization.

[22] PCO. (1961). 2nd Population and Housing census survey; District Census Report of Bahawalpur: Pakistan Census Organization.

[23] PCO. (1972). 3rd Population and Housing Census Survey; District Census Report of Bahawalpur: Pakistan Census Organization.

[24] PCO. (1981). 4th Population and Housing Census Survey; District Census Report of Bahawalpur: Pakistan Census Organization.

[25] PCO. (1999). Fifth Population and Housing Census of 1998 in District Census Report: Bahawalpur: Pakistan Census Organization.

[26] PDS. (2012). Punjab Development Statistics: Bureau of Statistics; Govt. of Punjab: Lahore.

[27] Pham, H. M., Yamaguchi, Y., \& Bui, T. Q. (2011). A case study on the relation between city planning and urban growth using remote sensing and spatial metrics. Landscape and Urban Planning, 100(3), 223-230. doi: http://dx.doi.org/10.1 016/j.landurbplan.2010.12.009

[28] PRB. (2013). World Population Data Sheet: Population Reference Bureau.

[29] Puertasa, O. L., Henríquez, C., \& Meza, F. J. (2014). Assessing spatial dynamics of urban growth using an integrated land use model. Application in Santiago Metropolitan Area, 2010-2045. Land UsePolicy, 38(2014), 415-425.

[30] Tian, G., Liu, J., Xie, Y., Yang, Z., Zhuang, D., \& Niu, Z. (2005). Analysis of spatio-temporal dynamic pattern and driving forces of urban land in China in 1990s using TM images and GIS. Cities, 22(6), 400-410. doi: http://dx.doi.org/10.1016/j.cities.2005.05.009

[31] Tisdale, H. (1941). The Process of Urbanization. Soc. F., 20, 311.

[32] UN. (1974). Manuals on methods of estimating population: Methods for projections of Urban and Rural Population. New York: Department of economic and social affairs: United Nations.

[33] UNHABITAT. (2010). State of the World's Cities 2010/2011: Bridging the Urban Divide. : Earthscan, London/Sterling, VA.

[34] Xiao, J., Shen, Y., Ge, J., Tateishi, R., Tang, C., Liang, Y., \& Huang, Z. (2006). Evaluating urban expansion and land use change in Shijiazhuang, China, by using GIS and remote sensing. Landscape and urban planning, 75(1), 69-80.

[35] Xu, X., \& Min, X. (2013). Quantifying spatiotemporal patterns of urban expansion in China using remote sensing data. Cities, 35, 104-113. doi: http://dx.doi.org/10.1016/j.citi es.2013.05.002

[36] Zhang, H., Qi, Z. f., Ye, X. y., Cai, Y. b., \& Ma, W. c. (2013). Analysis of land use/land cover change, population shift, and their effects on spatiotemporal patterns of urban heat islands 
in metropolitan Shanghai, China. Applied Geography, 44, 121-133.

[37] Zhang, Z., Su, S., Xiao, R., Jiang, D., \& Wu, J. (2013).
Identifying determinants of urban growth from a multi-scale perspective: A case study of the urban agglomeration around Hangzhou Bay, China. Applied Geography, 45(0), 193-202. doi: http://dx.doi.org/10.1016/j.apgeog.2013.09.013 